\title{
OPTIMALISASI PENERAPAN PRINSIP GOOD GOVERNANCE BIDANG AKADEMIK DALAM UPAYA MEWUJUDKAN GOOD UNIVERSITY GOVERNANCE
}

\author{
Hery Harjono Muljo; Aries Wicaksono; Ignatius Edward Riantono \\ Accounting and Finance Department, Faculty of Economic and Communication, BINUS University \\ Jln. K.H. Syahdan No.9, Palmerah, Jakarta Barat 11480 \\ heryhm@binus.edu; aries.0202@gmail.com; iriantono@binus.ac.id
}

\begin{abstract}
This study wants to know and understand whether good governance principles have been well applied as well as the factors influencing optimization of the implementation of good governance principles on the academic field in an effort to realize good university governance in Bina Nusantara University. The study aims to evaluate the implementation of good governance principles on the academic field, know the factors that affect the implementation of good governance principles on the academic field, and improve and develop the academic areas in accordance with good governance principles in order to maximize the role of Bina Nusantara University as Good University Governance. The approach model used to understand the implementation of good governance principles was a model to educational institution using the 8 principles, namely academic freedom, shared governance, clear rights and responsibilities, selection at merit, financial stability, accountability, regular testing of standards, and the importance of close cooperation. Research used qualitative method with descriptive analysis, by analyzing the factors influencing optimization of the implementation of good governance principles, particularly on academic areas. The results achieved there were 18 factors that affect the optimization of the implementation of good governance principles. Then the factors affected the optimization of the implementation of good governance principles the most are operational centralization and academic decentralization which were the novelty of this study.
\end{abstract}

Keywords: good university governance, optimization, academic

\begin{abstract}
ABSTRAK
Latar belakang dari penelitian ini ingin mengetahui dan memahami apakah prinsip good governance telah diterapkan dengan baik serta faktor yang memengaruhi optimalisasi penerapan prinsip good governance khusus di bidang akademik dalam upaya mewujudkan good university governance di Universitas Bina Nusantara. Penelitian bertujuan untuk mengevaluasi penerapan prinsip good governance pada bidang akademik, mengetahui faktor yang memengaruhi penerapan prinsip good governance pada bidang akademik, dan memperbaiki dan mengembangkan area-area akademik yang sesuai dengan prinsip-prinsip Good Governance guna memaksimalkan peran Universitas Bina Nusantara sebagai Good University Governance. Model pendekatan yang dipakai untuk memahami penerapan prinsip good governance adalah pendekatan model institusi pendidikan dengan menggunakan 8 prinsip, yaitu academic freedom, shared governance, clear rights and responsibilities, selection at merit, financial stability, accountability, regular testing of standards, dan importance of close cooperation. Metode yang digunakan dalam penelitian ini adalah metode kualitatif bersifat deskriptif analitis, dengan menganalisis faktor-faktor yang memengaruhi optimalisasi penerapan prinsip good governance khususnya bidang akademik. Hasil yang dicapai adalah terdapat 18 faktor yang memengaruhi optimalisasi penerapan prinsip good governance dan fator yang paling berpengaruh terhadap optimalisasi penerapan prinsip good governance adalah faktor sentralisasi operasi dan desentralisasi akademik yang merupakan kebaharuan dari penelitian ini.
\end{abstract}

Kata kunci: good university governance, optimalisasi, akademik 


\section{PENDAHULUAN}

Corporate Governance merupakan serangkaian mekanisme yang mengarahkan dan mengendalikan suatu perusahaan agar operasional perusahaan berjalan sesuai dengan harapan para pemangku kepentingan (stakeholders). Good Corporate Governance (GCG) merupakan struktur, sistem, dan proses yang digunakan oleh organ-organ perusahaan sebagai upaya untuk memberi nilai tambah perusahaan secara berkesinambungan dalam jangka panjang, dengan tetap memerhatikan kepentingan stakeholder lainnya, berlandaskan moral, etika, budaya dan aturan berlaku lainnya. (IICG, 2013)

Penerapan Good Governance akhir-akhir ini dirasakan sangat perlu. Hal ini dapat dilihat dari munculnya kekhawatiran di beberapa negera besar seperti Amerika Serikat. Di sana terjadi kegagalan dalam tata kelola perusahaan seperti Enron dan WorldCom yang bermasalah dengan tata kelola. Selain itu, Australia memiliki kasus tersendiri yang berkaitan dengan tata kelola perusahaan seperti gagalnya pengelolan perusahaan besar, antara lain gagalnya penanganan pengelolaan tata kelola valuta asing pada National Australia Bank. (HIH 2003, APRA 2004)

Berdasarkan Peraturan Menteri Keuangan No: 119/PMK.05/2007 pasal 5, pola tata kelola merupakan peraturan internal universitas yang menetapkan bahwa organisasi dan tata laksana mencakup struktur organisasi, prosedur kerja, pengelompokan fungsi yang logis, ketersediaan dan pengembangan sumber daya manusia serta efisiensi biaya; akuntabilitas mencakup kebijakan mekanisme/prosedur, media pertanggungjawaban, dan periodisasi pertanggungjawaban program, kegiatan dan keuangan dalam rangka mencapai tujuan yang telah ditetapkan, dan transparansi, dengan menerapkan asas keterbukaan yang dibangun atas dasar kemudahan memperoleh informasi bagi yang membutuhkan.

Pencapaian Good University Governance sangat dipengaruhi oleh satuan pengawasan internal (Puspitarini, 2012). Good Governance juga dipengaruhi oleh peran auditor internal. Makin meningkat peran auditor, maka akan memengaruhi peningkatan tata kelola suatu institusi pendidikan (Sukirman \& Sari, 2012).

Partisipasi fakultas dalam pengambilan keputusan memiliki peran yang sangat penting karena fakultas memiliki informasi yang lebih baik (Brown Jr, 2001). Penerapan good governance pada sektor publik juga ternyata dapat memberikan peningkatan perlindungan pada stakeholder (Hussaina \& Rajapakse, 2011). Struktur governance yang independen dan menerapkan best practice governance secara universal sangat tepat untuk menerapkan indikator corporate governance untuk mengevaluasi mekanisme tata kelola universitas (Silva \& Armstrong, 2012)

Model governance tiap institusi berbeda-beda. Prinsip-prinsip good university governance yang dapat menghasilkan income yaitu: law-abiding, academic oriented, accountable, professional, independent, dan transparent (Siswanto, Ely, Djumahir, Sonhadji, Idrus, 2013). Namun pendapat lain juga mengemukakan prinsip-prinsip governance secara umum yang berlaku di institusi (Aurangzeb \& Asif, 2012). Pertama academic freedom, membahas mengenai hak utama bagi seorang akademisi untuk melakukan penelitian, pengajaran, dan mempublikasikan hasil karya penelitian tanpa batasan dari instansi yang menugaskan para akademisi tersebut. Kebebasan akademik yang dimaksud dalam hal ini dapat dibagi menjadi 3 aspek yaitu kebebasan dalam melakukan penelitian, pengajaran dan publikasi hasil karya penelitian yang bermanfaat untuk meningkatkan kualitas baik, lembaga maupun sistem secara keseluruhan. 
Kedua shared governance, dikenal sebagai tata kelola yang kooperatif yang sangat penting untuk mencapai tata kelola yang baik. Untuk itu harus dipastikan bahwa setiap keputusan yang dibuat harus dibuat oleh orang yang memiliki kapabilitas. Hal ini berarti setiap jurusan mempunyai peran dalam membentuk kebijakan dan menjamin setiap jurusan diberikan suara yang sama saat menentukan kebijakan.

Ketiga, clear rights and responsibilities. Untuk mencapai tata kelola yang baik, hak dan tanggung jawab harus disepakati bersama untuk setiap aspek dalam sistem pendidikan karena hak dan tanggung jawab merupakan hal yang sangat penting. Peran kementerian pendidikan tinggi telah dinyatakan dalam hukum dan kebijakan. Untuk itu, bagaimana penerapan aturan hak dan kewajiban bagi mahasiswa dan jurusan.

Keempat selection at merit, dalam setiap proses perekrutan, promosi, dan penentuan jabatan, maka harus menghindari setiap unsur-unsur nepotisme, kronisme (mengutamakan kelompoknya sendiri), dan inbreeding yang dapat memengaruhi kualitas staf ataupun dosen yang direkrut atau yang dipromosikan.

Kelima financial stability dibutuhkan bagi institusi pendidikan tinggi untuk terus berkembang. Perencanaan yang rasional dan tata kelola yang baik tidak mungkin terwujud bagi institusi pendidikan tinggi di negara berkembang jika mengalami ketidakpastian keuangan, fluktuasi budget yang tajam, dan politis. Dalam hal ini penyusunan budget atau anggaran yang dibuat oleh masing-masing jurusan harus memerhatikan ketidakpastian keuangan, fluktuasi budget yang tajam, dan politis agar tercapai stabilitas keuangan.

Keenam accountability, mensyaratkan kepada institusi pendidikan tinggi untuk membuat pertanggungjawaban secara periodik mengenai kegiatan, keberhasilan serta kegagalan di institusi tersebut. Pertanggungjawaban diberikan institusi pendidikan tinggi kepada sponsor institusi tersebut baik publik maupun swasta.

Ketujuh regular testing of standards, sebagai bagian dari tata kelola yang baik, setiap institusi mensyaratkan bahwa setiap orang atau unit yang bertanggung jawab atas tata kelola harus melakukan review dan verifikasi terhadap standar yang ada. Terakhir, importance of close cooperation, kerja sama yang erat dan kompatibilitas antara berbagai tingkat administrasi kelembagaan diperlukan untuk mewujudkan tata kelola yang baik guna mencegah dan menghindari kontraproduktif, situasi permusuhan, atau masalah khusus lainnyaKerjasama yang erat dan kompatibilitas antara berbagai tingkat administrasi kelembagaan diperlukan untuk mewujudkan tata kelola yang baik guna mencegah dan menghindari kontraproduktif, situasi permusuhan, atau masalah khusus lainnya.

Penelitian ini bertujuan untuk mengevaluasi penerapan prinsip-prinsip good governance pada bidang akademik, mengetahui faktor-faktor yang memengaruhi penerapan prinsip-prinsip good governance pada bidang akademik, dan memperbaiki dan mengembangkan area-area akademik yang sesuai dengan prinsip-prinsip Good Governance guna memaksimalkan peran institusi sebagai Good University Governance. Sedangkan manfaat yang diharapkan dari penelitian ini adalah memperoleh informasi mengenai penerapan 8 prinsip good governance khusus di bidang akademik, dan memberikan rekomendasi perbaikan dan pengembangan di area-area akademik yang dinilai belum maksimal dalam menerapkan prinsip good governance guna pencapaian peran institusi sebagai Good University Governance. 


\section{METODE}

Metode yang digunakan dalam penelitian ini adalah metode kualitatif bersifat deskriptif analitis, dengan menganalisis faktor-faktor yang memengaruhi optimalisasi penerapan prinsip good governance khususnya bidang akademik. Objek penelitian dilakukan di Universitas Bina Nusantara khususnya di jurusan dan di unit yang menangani bidang akademik. Teknik pengumpulan data yang digunakan dalam penelitian ini adalah survei, wawancara, dan forum group discussion. Survei dilakukan di 3 unit yang berbeda yaitu bagian ARC, jurusan Hotel Manajemen, dan jurusan Akuntansi. Wawancara dilakukan untuk mengonfirmasikan setiap data yang dapat, kejelasan dari setiap prosedur yang dijalankan, dan penjelasan lain yang belum didapat saat survei dilakukan. Personel yang akan diwawancarai adalah pimpinan jurusan serta section head yang lebih memahami setiap proses.

Selain wawancara, forum group discussion juga dilakukan dengan unit Academic Resource Center. Diskusi difokuskan pada pencarian informasi mengenai pembuatan kurikulum, penunjukan pembuat kurikulum, dan operasional lainnya yang berhubungan dengan kurikulum. Luaran yang dihasilkan berupa rekomendasi untuk perbaikan dan pengembangan unit khususnya untuk meningkatkan tata kelola universitas yang baik. Indikator ketercapaian penelitian ini dapat diukur dengan terbentuknya rekomendasi dan pengembangan yang dapat meningkatkan prinsip-prinsip tata kelola universitas yang baik.

\section{HASIL DAN PEMBAHASAN}

\section{Academic Freedom}

Academic Freedom membahas mengenai hak utama bagi seorang akademisi untuk melakukan penelitian, pengajaran, dan mempublikasikan hasil karya penelitian tanpa batasan dari instansi yang menugaskan para akademisi tersebut. Kebebasan akademik yang dimaksud dalam hal ini dapat dibagi menjadi 3 aspek yaitu kebebasan dalam melakukan penelitian, pengajaran dan publikasi hasil karya penelitian yang bermanfaat untuk meningkatkan kualitas baik, lembaga maupun sistem secara keseluruhan.

Dari sisi kebebasan penelitian, didapatkan beberapa fakta yang terkait dengan academic freedom yaitu tiap dosen diberikan kesempatan untuk melakukan penelitian baik yang dibiayai oleh institusi maupun pihak eksternal, yaitu DIKTI, DEPTAN, MENRISTEK, dan banyak pihak lainnya yang difasilitasi Research Office. Para peneliti bebas mengajukan usulan penelitian dengan mematuhi rambu-rambu yang telah ditetapkan yaitu harus berdasarkan roadmap penelitian masing-masing jurusan serta sesuai dengan kompetensi dari tiap-tiap dosen yang mengajukan. Bagi dosen yang belum memiliki jenjang akademik, ia hanya dapat mengikuti penelitian yang didanai internal institusi.

Dari sisi kebebasan mengajar, didapatkan beberapa fakta yang terkait dengan academic freedom yaitu setiap dosen diberikan kebebasan untuk mengajar sesuai dengan kompetensi yang dimiliki. Setiap dosen dikelompokkan berdasarkan rumpun ilmu yang telah ditetapkan oleh jurusan masing-masing. Pengelompokan yang dibuat jurusan berdasarkan subilmu dari jurusan tersebut. Berikut pengelompokan rumpun ilmu di jurusan akuntansi dikelompokan menjadi akuntansi manajemen, auditing, perpajakan, sistem informasi akuntansi dan keuangan. Dosen dapat masuk ke rumpun ilmu yang telah ditetapkan dengan mempertimbangkan latar belakang pendidikan, pengalaman bekerja, dan pengalaman penelitian. Setiap dosen diberi hak untuk mengajar minimal 8 SKS dan maksimal 12 SKS. Untuk kondisi tertentu seorang dosen diperkenankan mengajar lebih dari 
12 SKS. Metode pengajaran telah ditetapkan oleh jurusan berdasarkan course outline yang telah dibuat, tetapi setiap dosen diberikan kebebasan untuk memilih metode pengajaran yang dianggap efektif saat penyampaian materi.

Dari sisi kebebasan mempublikasikan hasil karya penelitian, didapatkan beberapa fakta yang terkait dengan academic freedom yaitu setiap dosen diberi kebebasan untuk mempublikasikan hasil karya penelitiannya. Untuk mempublikasikan hasil karya penelitian, dosen difasilitasi Research Office dalam hal mencarikan jurnal yang dituju, menerjemahkan bahasa, dan mengedit artikel ilmiah sebelum dikirimkan ke penerbit jurnal.

\section{Shared Governance}

Shared governance juga dikenal sebagai tata kelola yang kooperatif yang sangat penting untuk mencapai tata kelola yang baik. Untuk itu harus dipastikan bahwa setiap keputusan yang dibuat harus dibuat oleh orang yang memiliki kapabilitas. Hal ini berarti setiap jurusan mempunyai peran dalam membentuk kebijakan dan menjamin setiap jurusan diberikan suara yang sama saat menentukan kebijakan.

Beberapa fakta yang berkaitan dengan shared governance yaitu institusi menganut sistem SODA (Sentralisasi Operasional Desentralisasi Akademik). Artinya, setiap keputusan dan kebijakan akademik diserahkan kepada tiap fakultas dan Prodi terkait yang dikoordinasikan Wakil Rektor I (Bidang Akademik). Sedangkan untuk pelaksanaan keputusan tersebut dikoordinasikan Wakil Rektor II.

Kewenangan jurusan dalam menentukan kebijakan antara lain pertama kebijakan pembuatan kurikulum maupun pengajaran. Jurusan diberikan kebebasan untuk menentukan hal yang terkait dengan kurikulum di masing-masing jurusan, baik dari sisi struktur mata kuliah dan peminatan. Sedangkan yang berkaitan dengan pengajaran jurusan memiliki kebijakan dalam penugasan dosen dalam mengajar.

Kedua kebijakan dalam menentukan persyaratan penerimaan dosen. Seleksi calon dosen tetap dilakukan melalui desk evaluation terhadap kelengkapan dokumen administrasi serta kesesuaian latar belakang pendidikan, pengalaman dan sertifikasi dengan Prodi Akuntansi. Jika calon dosen tersebut adalah dosen baru maka ia wajib untuk mengikuti tes sebagai berikut: (i) tes komputer yang diadakan oleh LRC (ii) tes bahasa Inggris yang diadakan oleh LRC dan Language Centre. Jika calon dosen tersebut lulus dari kedua tes tersebut, yang bersangkutan akan mengikuti assessment Psikologi yang diadakan LRC bekerja sama dengan Prodi Psikologi dan Direktorat Talent Management.

Selanjutnya calon dosen mengikuti tes demo teaching bersama Prodi. Materi tes demo teaching telah ditentukan sebelumnya dan biasanya memakan waktu antara 30-45 menit. Setelah tes tersebut dilalui maka dilakukan evaluasi tahap lanjut bersama Wakil Rektor 1, Dekan, Ketua Prodi dan Direktorat Talent Management untuk memutuskan apakah FM (dosen tetap) atau AFM (Associate Faculty Member/dosen tidak tetap) tersebut bisa diterima di UBINUS atau tidak. Setelah persetujuan akhir didapatkan oleh pihak-pihak tersebut, LRC kemudian membuat surat penerimaan/penolakan untuk diteruskan ke pihak Rektorat guna menerbitkan kode dosen baru serta surat panggilan untuk mengikuti kegiatan pelatihan induksi dosen. Setelah mengikuti pelatihan induksi tersebut, kemudian diterbitkan SK pengangkatan sebagai dosen baru dan secara bersamaan dimasukkan dalam arsip data dosen.

Ketiga kebijakan dalam menentukan kelulusan mahasiswa. Kurikulum jurusan disusun dengan menggunakan pendekatan kompetensi lulusan (graduate competences) dari sisi teknik dan pengetahuan, yang dilengkapi dengan employability and entrepreneurship (EES) skills, information 
and communication technology (ICT) skills, foreign language skills ditambah dengan international experience. Dengan demikian setiap lulusan telah memperoleh bekal dan kemampuan untuk terjun di dunia kerja.

Keempat kebijakan penyelenggaraan praktikum. Setiap jurusan menyediakan fasilitas laboratorium antara lain perangkat lunak (lab. softwate), praktikum akuntansi, mata kuliah bahasa Inggris, lab. teknik industri, lab. perhotelan, dan penggunaan lab. bahasa jika dibutuhkan serta kunjungan langsung ke industri untuk melatih ketrampilan yang dibutuhkan. Penyelenggaraan lab diatur jurusan sesuai dengan jadwal kuliah mahasiswa.

\section{Clear Rights and Responsiblities}

Untuk mencapai tata kelola yang baik, hak dan tanggung jawab harus disepakati bersama untuk setiap aspek dalam sistem pendidikan karena hak dan tanggung jawab merupakan hal yang sangat penting. Peran kementerian Pendidikan Tinggi telah dinyatakan dalam hukum dan kebijakan. Untuk itu bagaimana penerapan aturan hak dan kewajiban bagi mahasiswa, dan jurusan.

Hak dan kewajiban mahasiswa sudah tertulis pada buku pedoman mahasiswa yang telah disosialisasikan ke mahasiswa ketika mahasiswa mengikuti program Freshmen Enrichment Program (FEP). Setiap mahasiswa diwajibkan menandatangani aturan yang berlaku di kampus. Hal yang sama juga berlaku bagi dosen yang setiap hak dan kewajiban dosen telah dinyatakan pada surat perjanjian saat dosen tersebut telah menjadi faculty member dan harus ditandatangani.

Penerapan hak dan kewajiban jurusan dikaitkan dengan kinerja jurusan. Setiap jurusan mempunyai performance indicator yang merupakan alat ukur kinerja bagi jurusan. Berikut kewajiban jurusan yaitu setiap jurusan diwajibkan mencapai Performance Indicator minimal 4, membuat laporan bulanan dan tahunan yang berisikan mengenai pencapaian kinerja dan penyerapan anggaran, dan membuat laporan keuangan yang berisikan pemakaian anggaran dan melaporan kegiatan nontuition fee.

Sedangkan hak jurusan antara lain merencanakan anggaran yang merupakan dasar bagi jurusan untuk mencapai Performance Indicator yang telah ditetapkan. Hasil perencanaan anggaran diserahkan seluruhnya ke jurusan dan pengelolaannya difasilitasi bagian keuangan. Selain itu merencanakan program kerja yang berhubungan dengan kurikulum, pengajaran penelitian, pengabdian, dan professional services.

\section{Selection At Merit}

Dalam setiap proses perekrutan, promosi dan penentuan jabatan, maka setiap unsur-unsur nepotisme, kronisme (mengutamakan kelompoknya sendiri), dan inbreeding harus dihindari yang dapat memengaruhi kualitas staf ataupun dosen yang direkrut atau yang dipromosikan. Berikut hasil wawancara yang diperoleh dari jurusan yaitu:

Perekrutan atau sistem seleksi dosen disesuaikan dengan prosedur sistem manajemen mutu ISO 9001:2008 yaitu PR-BINUS 06-01. Prosedur dimulai dari permintaan Prodi ke LRC (Lecturer Resource Center) tentang kebutuhan dosen di Prodi. Kemudian langkah selanjutnya LRC membuat pengumuman tentang kebutuhan dosen baik melalui iklan atau media lainnya. Dosen yang tertarik menjadi dosen tetap bisa mengirimkan aplikasinya secara online melalui tautan: www.lecturervacancy.binus.ac.id. Dari hasil iklan dan pengiriman aplikasi secara online tersebut selanjutnya LRC mengumpulkan dokumen pelamar serta formulir lainnya yang telah disiapkan untuk diserahkan ke Prodi Akuntansi untuk mengikuti seleksi calon dosen tetap. 
Sedangkan proses perekrutan untuk staf administrasi dilakukan dengan mengisi formulir permintaan tenaga kerja yang kemudian diserahkan ke bagian Human Capital untuk ditindaklanjuti antara lain dipanggil untuk mengikuti penilaian psikologi dan tes bahasa inggris. Dalam kenyataan memang ditemukan pasangan suami istri yang bekerja dalam satu institusi yang sama namun berbeda unit atau departemen. Hal ini tidak dapat dikatakan sebagai inbreeding murni karena saat proses penerimaan karyawan, mereka berstatus single. Melihat dari proses, dapat disimpulkan tidak terjadi unsur-unsur yang terkait dengan nepotisme, kronisme, dan inbreeding.

\section{Financial Stability}

Stabilitas keuangan yang cukup dibutuhkan bagi institusi pendidikan tinggi untuk terus berkembang. Perencanaan yang rasional dan tata kelola yang baik tidak mungkin terwujud bagi institusi pendidikan tinggi di negara berkembang jika mengalami ketidakpastian keuangan, fluktuasi budget yang tajam dan politis. Dalam hal ini jurusan penyusunan budget atau anggaran yang dibuat oleh masing-masing jurusan harus memerhatikan ketidakpastian keuangan, fluktuasi budget yang tajam, dan politis agar tercapai stabilitas keuangan.

Untuk menunjang kegiatan belajar mengajar dibutuhkan dukungan berbagai aspek, salah satu yang terpenting adalah dana. Penanganan pengelolaan keuangan dikendalikan oleh Direktorat Keuangan. Setiap tahun Prodi akan merencanakan program/kegiatan untuk tahun berikutnya. Pembicaraan mengenai rencana kerja dan aplikasi dana ditentukan di setiap Prodi dalam rapat antara para struktural jurusan, demikian juga dengan Prodi Akuntansi. Program kerja yang sudah disepakati oleh seluruh struktural jurusan kemudian dibicarakan dengan dekan, sebagai pemimpin Fakultas, untuk ditinjau ulang. Program atau rencana kerja ini kemudian dibahas pada tingkat rektorat dengan mengikutsertakan perangkat jurusan dalam satu presentasi anggaran, untuk menentukan kelayakan program serta biaya yang diajukan. Jika program rencana kerja tersebut telah disetujui, rencana kerja tersebut akan disahkan oleh rektor dan akan digunakan sebagai dasar pelaksanaan kegiatan Prodi.

Dalam pelaksanaannya pada saat akan melaksanakan kegiatannya Prodi akan mengajukan dana pelaksanaan sesuai dengan rencana kerja dan anggaran yang telah disetujui. Adapun anggaran biaya yang bersifat rutin (operasional perkuliahan, honor tenaga pengajar dan lain-lain) penganggaran dan pelaksanaannya dilakukan oleh Wakil Rektor II Bidang Manajemen Operasi dan Sumber daya.

Dengan demikian berarti setiap jurusan diberikan hak otonomi dalam penentuan anggaran. Sistem pembuatan anggaran bersifat bottom up, kemudian diputuskan oleh pimpinan universitas dengan mempertimbangkan ketiga faktor yang ada yaitu ketidakpastian keuangan, fluktuasi budget yang tajam dan kondisi politis dengan tujuan kestabilan keuangan dapat tercapai.

\section{Accountability}

Akuntabilitas mensyaratkan kepada institusi pendidikan tinggi untuk membuat pertanggungjawaban secara periodik mengenai kegiatan, keberhasilan serta kegagalan di institusi tersebut. Pertanggungjawaban diberikan institusi pendidikan tinggi kepada sponsor institusi tersebut baik publik maupun swasta.

Setiap jurusan wajib membuat laporan bulanan yang akan dikumulatifkan menjadi laporan kuartalan. Laporan bulanan secara umum mencatat setiap kegiatan yang telah dilaksanakan setiap bulannya beserta pelaporan realisasi pemakaian dana. Semua kegiatan yang terkait jurusan serta pencapaian jurusan baik yang sudah sesuai target ataupun yang belum harus dipertanggungjawabkan kepada pihak manajemen. Pertanggungjawaban pencapaian kinerja dilakukan pada setiap kuartal. Pada kuartal ke 4, setiap jurusan juga diminta untuk mempresentasikan seluruh pencapaian kinerja tersebut kepada pihak manajemen sedangkan untuk setiap kegiatan yang berada di bawah jurusan harus dipertanggungjawabkan kepada jurusan dalam bentuk laporan tertulis ke jurusan. 


\section{Regular Testing of Standards}

Sebagai bagian dari tata kelola yang baik, setiap institusi mensyaratkan bahwa setiap orang atau unit yang bertanggung jawab atas tata kelola harus melakukan review dan verifikasi terhadap standar yang ada. Universitas Bina Nusantara dalam menjalankan kegiatannya menggunakan pendekatan SODA (Sentralisasi Operasi Desentralisasi Akademik). Untuk mengendalikan sistem ini, pendekatan yang digunakan adalah standar sistem manajemen mutu berbasis ISO 9001:2008.

Sertifikat standar sistem mutu internasional ini diterapkan pada setiap unit yang terkait dengan proses perancangan dan pengembangan kurikulum dan materi perkuliahan, proses belajar mengajar dan penelitian. Penggunaan sistem manajemen ini memungkinkan adanya pengendalian yang lebih terarah dalam pencapaian visi dan misi menggunakan standar sistem manajemen Mutu ISO 9001.

Dalam satu (1) tahun dilakukan satu kali audit internal yang dilaksanakan antara bulan maret sampai dengan agustus, dan satu kali audit eksternal yang dilakukan sekitar bulan September. Hal ini bertujuan untuk mereview dan memverifikasi setiap standar yang telah dibuat. Hal ini berguna untuk memastikan apakah standar yang dibuat telah dilaksanakan dengan baik atau tidak.

\section{Importance of Close Cooperation}

Kerja sama yang erat dan kompatibilitas antara berbagai tingkat administrasi kelembagaan diperlukan untuk mewujudkan tata kelola yang baik guna mencegah dan menghindari kontraproduktif, situasi permusuhan, atau masalah khusus lainnya.

Sistem Sentralisasi Operasi Desentralisasi Akademik (SODA) merupakan sistem yang dibuat dengan mengkaitkan antara bagian dan departemen. Seluruh proses akademik ditunjang sepenuhnya oleh sistem yang dijalankan bagian penunjang. Satu kegiatan akademik dapat didukung oleh satu atau lebih unit pendukung. Satu unit pendukungnya terkadang harus didukung oleh unit penunjang lainnya. Dengan demikian seluruh bagian dan departemen yang ada secara otomatis melakukan kerja sama antarbagian dan departemen. Research Office merupakan bagian yang menunjang seluruh jurusan yang ada guna menjalankan program kerja penelitian dan publikasi. Research Office bekerja sama dengan bagian Lecture Resource Center (LRC) untuk mendukung dosen khususnya butir penelitian dan publikasi yang akan digunakan untuk proses peningkatan jenjang jabatan akademik dosen. Research Office juga berhubungan dengan bagian kemahasiswa khususnya membantu jurusan dalam pelaksanaan penelitian mahasiswa dan program kegiatan mahasiswa lainnya. Selain itu Research Office juga berhubungan dengan bagian library khususnya dalam hal mengarsip dan mengunggah hasil karya penelitian dosen dalam bentuk publikasi ilmiah. Research Office juga bekerja sama dengan pihak luar antara lain kementerian pendidikan, departemen pertanian, dan banyak departemen lainnya.

\section{SIMPULAN}

Penelitian ingin mengetahui faktor-faktor yang memengaruhi optimalisasi penerapan prinsip good governance pada bidang akademik dalam upaya mewujudkan good university governance. Untuk memahami penerapan prinsip good governance digunakan 8 prinsip berdasarkan pendekatan model institusi pendidikan yaitu academic freedom, shared governance, clear rights and responsibilities, selection at merit, financial stability, accountability, regular testing of standards, dan importance of close cooperation. Berdasarkan hasil analisis, ditemukan faktor-faktor yang memengaruhi optimalisasi penerapan good governance berdasarkan 8 prinsip dengan pendekatan model institusi pendidikan. Pada prinsip academic freedom, terdapat 4 faktor yang memengaruhi optimalisasi penerapan good governance yaitu kesempatan, pendanaan, kompetensi, dan metode 
pengajaran. Pada prinsip shared governance, terdapat 2 faktor yang memengaruhi optimalisasi penerapan good governance yaitu kebijakan sentralisasi operasi, dan kebijakan desentralisasi akademik. Pada prinsip Clear Rights and Responsibilities, terdapat 2 faktor yang memengaruhi optimalisasi penerapan good governance yaitu kesepakatan antara hak dan kewajiban, dan peran serta Perguruan Tinggi. Pada prinsip selection at merit, terdapat 2 faktor yang memengaruhi optimalisasi penerapan good governance yaitu proses perekrutan, promosi dan penentuan jabatan yang bersih, dan kejelasan proses penerimaan yang jelas dan tertulis. Pada prinsip financial stability, terdapat 2 faktor yang memengaruhi optimalisasi penerapan good governance yaitu perencanaan anggaran yang matang dan kepastian pendanaan. Pada prinsip accountability, terdapat 2 faktor yang memengaruhi optimalisasi penerapan good governance yaitu laporan secara berkala, dan pertanggungjawaban kegiatan. Pada prinsip regular testing of standards, terdapat 2 faktor yang memengaruhi optimalisasi penerapan good governance yaitu review standar secara periodik dan penanggung jawab tata kelola. Pada prinsip importance of close cooperation, terdapat 2 faktor yang memengaruhi optimalisasi penerapan good governance yaitu kerja sama yang erat dan saling mendukung.

\section{Keterbatasan Penelitian}

Hasil penelitian ini masih penuh dengan keterbatasan. Objek penelitian dilakukan pada 2 jurusan yaitu jurusan Akuntansi dan jurusan Manajemen Perhotelan dan pada 1 bagian yaitu Academic Resources Center (ARC). Proses yang diteliti juga hanya sebatas pada kegiatan akademik dan operasional. Dengan demikian bagi peneliti lain yang akan melanjutkan penelitian ini, dapat memperluas objek penelitian, dari yang awalnya hanya 2 jurusan dan 1 bagian, dapat memperluas menjadi seluruh jurusan dan seluruh bagian yang mendukung jurusan. Selain itu proses yang diteliti dapat diperluas juga, bukan hanya akademik dan operasional melainkan seluruh proses yang ada.

\section{Saran}

Pada prinsip selection at merit, jika ditemukan karyawan dengan status sudah menikah dan keduanya bekerja di institusi yang sama, disarankan untuk mengambil keputusan siapa yang harus diganti. Hal ini guna mendukung terbentuknya optimalisasi penerapan good governance yang tidak memperkenankan terjadinya nepostisme, kronisme, dan inbreeding.

\section{DAFTAR PUSTAKA}

Aurangzeb, Asif, K. (2012). Good governance in universities, and prospects of employment for the students: evidence from Pakistan. Universal Journal of Management and Social Sciences, 2(11), 86-103.

Australian Prudential Regulatory Authority (APRA). (2004). Report into Irregular Currency Options Trading at the National Australia Bank, Commonwealth of Australia 2004. Diakses dari http://www.nabgroup.com/vgnmedia/downld/APRAreport_24march04.pdf

Brown Jr, W. O. (2001). Faculty participation in university governance and the effects on university performance. Journal of Economic Behavior \& Organization, 44(2), 129-143.

HIH. (2003). Royal Commission Report, Commonwealth of Australia, Canberra, 2003. Diakses dari http://www.hihroyalcom.gov.au/

Peraturan Menteri Keuangan No: 119/PMK.05/2007 pasal 5 
Puspitarini, N.D. (2012). Peran Satuan Pengawasan Intern Dalam Pencapaian Good University Governance Pada Perguruan Tinggi Berstatus PK-BLU. Accounting Analysis Journal. Vol 1 (2), $1-8$

Silva, C. D., Armstrong, A. (2012). Evaluation of corporate governance masures: an application to the Australian higher education sector. Journal of Business Systems, Governance and Ethics, 7(1), 76-86.

Siswanto, Ely, Djumahir, Sonhadji, A., Idrus, M. S. (2013). Good university income generating governance in Indonesia: agency theory perspective. International Journal of Learning \& Development, 3(1), 67-78.

Sukirman \& Sari, M.P. (2012). Peran internal audit dalam upaya mewujudkan Good University Governance di UNNES. Jurnal Dinamika Akuntansi, 4(1), 64-71.

The Indonesian Institute For Corporate Governance (IICG). (2013). Diakses dari http://iicg.org/v25/tata-kelola-perusahaan 